\title{
The effect of replacement of fish meal with Amino Acids and Optimized Protein Levels in the diet of the Nile Tilapia Oreochromis niloticus
}

\author{
A-W. Abdel-Warith ${ }^{1,2}$, N. Al-Asgah ${ }^{1}$, Y. El-Sayed ${ }^{1}$, A. El-Otabyl and S. Mahboob ${ }^{1,3 *}$ \\ ${ }^{1}$ Department of Zoology, College of Science, King Saud University, Riyadh, Saudi Arabia \\ ${ }^{2}$ Department of Animal Production, Faculty of Agriculture, Al-Azhar University, Nasr City, Cairo, Egypt \\ ${ }^{3}$ Department of Zoology, GC University, Faisalabad, Pakistan \\ *e-mail: shahidmahboob60@hotmail.com
}

Received: December 21, 2017 - Accepted: February 19, 2018 - Distributed: November 30, 2019

\begin{abstract}
This study was conducted to determine an appropriate replacement of fishmeal with amino acids (AAs) and optimized protein levels in practical diets for Oreochromis niloticus with mean initial body weight $12.52 \pm 0.63 \mathrm{~g}$. Six experimental and a control diet (total 7 diets) divided into two groups, and a control diet (D1) containing 32\% protein. The first group contained three diets that included different dietary protein levels, viz. 20 (D2), 25 (D3), and 30\% (D4) with AAs when replacing fishmeal by plant protein sources. In the second group, the diets were contained 20 (D5), 25 (D6), and 30\% (D7) without AAs. The best growth performance was achieved in fish fed with diet D1. Total feed intake was increased with an increase in dietary protein level with AAs. The specific growth rate showed a similar pattern with a significant difference between control, D4 and D7 compared to other groups. The feed conversion ratio decreased when protein levels in the diets increased. The protein efficiency ratio showed a similar performance, with a slight increase between the control diet and diets with AAs. However, insignificant differences $(\mathrm{P}>0.05)$ were observed between diets with and without AAs. An economic evaluation indicated that inclusion of low fishmeal in tilapia diets reduced the price $/ \mathrm{kg}$ of diets compared to control.
\end{abstract}

Keywords: amino acids supplementation, economic evaluation, growth performance, plant ingredients.

\section{O efeito da substituição da farinha de peixe por Aminoácidos e Níveis Otimizados de Proteína na dieta da tilápia do Nilo Oreochromis niloticus}

\begin{abstract}
Resumo
Este estudo foi realizado para determinar uma substituição adequada de farinha de peixe com aminoácidos (AA) e níveis otimizados de proteína em dietas práticas para Oreochromis niloticus com peso corporal inicial médio de $12,52 \pm 0,63 \mathrm{~g}$. Seis dietas experimentais e controle (total de 7 dietas) divididas em dois grupos, e uma dieta controle (D1) contendo $32 \%$ de proteína. O primeiro grupo continha três dietas que incluíam diferentes níveis de proteína na dieta, viz. 20 (D2), 25 (D3) e 30\% (D4) com AAs ao substituir a farinha de peixe por fontes de proteína vegetal. No segundo grupo, as dietas continham 20 (D5), 25 (D6) e 30\% (D7) sem AAs. O melhor desempenho de crescimento foi alcançado em peixes alimentados com dieta D1. O consumo total de ração foi aumentado com o aumento do nível de proteína na dieta com AAs. A taxa de crescimento específico mostrou um padrão semelhante com uma diferença significativa entre o controle, D4 e D7 em comparação com outros grupos. A taxa de conversão alimentar diminuiu quando os níveis de proteína nas dietas aumentaram. A taxa de eficiência protéica apresentou desempenho semelhante, com discreto aumento entre a dieta controle e as dietas com AAs. Entretanto, diferenças insignificantes $(P>0,05)$ foram observadas entre dietas com e sem AAs. Uma avaliação econômica indicou que a inclusão de farinha de peixe baixa em dietas de tilápia reduziu o preço / $\mathrm{kg}$ de dietas em relação ao controle.
\end{abstract}

Palavras-chave: suplementação de aminoácidos, avaliação econômica, desempenho de crescimento, ingredientes vegetais.

\section{Introduction}

The increasing cost of the strategic use of fish meal for higher value fish species means that it is necessary to consider economic diets for aquaculture and this is especially important for the non-carnivorous fish, other than

salmonids and sea basses that require high specification diets and where fishmeal is widely used. Considerable scholarly attention has, therefore, been concentrated on evaluating the use of plant protein sources, such as oil 
seeds, pulses, and cereals, in the context of commercial diets for fish.

Oreochromis niloticus is one of the most promising fish for freshwater culture, especially in South Asian countries $(\mathrm{FAO}, 2004)$ also, since it is an omnivorous fish with low mortality and rapid growth, it accepts artificial diets for all stages of production (El-Sayed, 2006). Fish meal has a sufficient and balanced content of amino acids when compared with plant protein sources that are often limited in some of the essential amino acids with consequent negative effects on growth and feed utilization when substituted for fish meal in diet formulations (Wilson, 1989). Economic feeds of tilapia contain about 5-10 percent of fish meal in the diet, but continuous price hike of fish meal forced the fish culturists to use certain supplementations (Naylor et al., 2000). The consideration has been given to tilapia nutrition with an attention on the partial or total substitution of fish meal by cheap vegetable protein sources in tilapia feeds (El-Sayed, 1999) such high levels of replacement plant vegetable sources, however, require supplementation of essential AAs in fish diets.

Fish body weight and age are important parameters for determining the content of protein diets to support efficient fish production. Some studies, however, have suggested that the total replacement of fish meal by vegetable protein affected growth performance of rainbow trout (Gomes et al., 1995) and Atlantic salmon (Espe et al., 2006). However, $100 \%$ replacement of fish meal in diets was possible for salmon with no negative impact on growth. The feed consumption of diet supplemented with amino acids in salmon was better compared to high concentrate fish meal feed (Espe et al., 2007; Ayisi et al., 2017).

Knowledge of the protein demands of fish during the rapid growth period is necessary for aquaculture practice to achieve maximum feed conversion and utilization, saving some of the costs, and reducing protein load in the aquatic environment (Abdel-Tawwab et al., 2010). Many researchers attempted to determine the substitution of fishmeal in feed for tilapia with cheap, indigenous plant, and animal sources of proteins (El-Saidy and Gaber, 2003; Gonzales Júnior et al., 2007; Lim et al., 2007; Zuo et al., 2017). However, more investigations are required to evaluate the performance of different combinations of alternative constituents to prepare a balanced tilapia diets. Koch et al. (2016) demonstrated that the available economical feeds for $O$. niloticus entail nutrient reduction or are unbalanced, such that the decreased feed utilization is likely to release unutilized protein, carbohydrates, and other constituents into, and cause eutrophication of, adjoining water reserviors (Montanhini Neto and Ostrensky, 2015). Meanwhile, Webster et al. (1999) reported that compounding animal and plant protein sources with additional amino acid profiles may enhance the possibility of nutrient inadequacy that could adversely affect fish growth. Fishmeal is successfully substituted with other vegetable protein sources in fish feeds, there is some concern that the current evaluations of essential amino acid requirements are unsatisfactory goal (Furuya et al., 2004), Some AAs may also turn into a limiting factor and thus need to be supplemented in feed for important species of fish (El-Sayed, 2014; Liu et al., 2017).

The main aim of this study were to define the effect of dietary protein level, Essential Amino Acid (EAA) supplementation as a replacement of fishmeal, and their interaction on growth, feed utilization, carcass composition, and the potential cost benefit to the aquaculture of Nile tilapia.

\section{Material and Methods}

\subsection{Collection of fish and growth trial}

Fingerlings of Nile tilapia, $O$. niloticus, were procured from the fish seed hatchery of King Abdulaziz City for Sciences and Technology, Riyadh, Saudi Arabia. Fish were acclimatised for two weeks before the experiment. A total of 315 fingerlings of $O$. niloticus, with an average body weight of $12.52 \pm 0.63 \mathrm{~g}$ and body length of $9.13 \pm 0.27 \mathrm{~cm}$, were assigned to this study. The fish were stocked into 21 glass aquaria containing 75 litres of dechlorinated tap water. Each feed was given with three replicates in factorial design. The water temperature was maintained at $28 \pm 1^{\circ} \mathrm{C}$ by thermostatically controlled immersion heaters. Water quality parameters were held within the desirable range for tilapia: $\mathrm{pH}$ 6.9-8.0, ammonia $\left(\mathrm{NH}_{3}\right) 0.08-0.21 \mathrm{mg} / \mathrm{L}$, nitrite $\left(\mathrm{NO}_{2}\right) 0.17-0.36 \mathrm{mg} / \mathrm{L}$, nitrate $\left(\mathrm{NO}_{3}\right) 4.28-5.71 \mathrm{mg} / \mathrm{L}$, and dissolved oxygen 5.9-7.4 mg/L (El-Sayed, 2014).

\subsection{Diet formulation}

Seven diets were formulated to include a control diet (D1), which contained $32 \%$ protein, while the other six diets were divided into two groups: a group containing three diets that included different dietary protein levels, that is, 20 (D2), 25 (D3) and 30\% (D4) with AAs supplementation in the form of methionine (Met 2\%) and lysine (Lys 1\%) achieved by replacing fishmeal with plant protein sources. In the second group, another three diets contained the same protein levels i.e. 20 (D5), 25 (D6) and 30\% (D7), replacing fishmeal by plant protein sources but without EAA supplementation. Table 1 displays the proximate analysis of the major dietary ingredients performed prior to the formulation of the experimental diets. The formulation and proximate composition of the diets are presented in Table 2.

\subsection{Growth studies}

Fish were weighed fortnightly and fed at $3 \%$ of body weight twice daily, in the morning at 8.00 am and evening at $6.00 \mathrm{pm}$. The feeding trial was conducted for 12 -week. At the end of the feeding experiment, five fish from each aquarium were killed for the determination of the proximate composition of fish meat. Growth and nutrient efficiency were calculated by following the equations 1-4 as described by Guo et al. (2012):

Weight gain $(W G)=(B W f-B W i)$

Where $\mathrm{BWi}=$ Initial body weight and $\mathrm{BWf}=$ Final body weight. 
Feed conversion ratio $(F C R, g)=\frac{\text { Feed intake }(g)}{\text { Weight gain }(g)}$

Protein efficiency ratio $($ PER $)=\frac{\text { Biomass }(g)}{\text { Protein intake }(g)}$

Specific growth rate (SGR)

Specific growth rate (SGR) was estimated according to Dhwan and Kaur (2002); that is:

$S G R=\frac{\operatorname{In}(\text { Final wet body weight })-\operatorname{In}(\text { Initial wet body weight }) \times 100}{\text { Time duration }(\text { days })}$

Protein productive values (PPV (\%): retained protein $(\mathrm{g}) /$ total protein intake $(\mathrm{g}) \times 100$.

\subsection{Proximate Composition}

Proximate chemical compositions of diets and fish tissue for moisture, protein, lipid, and ash were determined according to AOAC (1995).

\subsection{Determination of amino acids}

The amino acid analysis was performed with High performance liquid chromatography (HPLC, Shimadzu Co. Ltd, Kyoto, Japan) so as to analyze and quantify the amount of 15 amino acids in feeds +fertilizers +Pure Amino Acids (Feed Grade) and Premixes. Approximately 0.2-0.5 g of dry sample was weighed and hydrolysed with $50 \mathrm{ml}$ of $50 \% \mathrm{HCl}$ for 18 hours at $110^{\circ} \mathrm{C}$. A Sodium citrate buffer, $\mathrm{PH}=2.2$, was used to make the solution up to $100 \mathrm{ml}$. The sample was then dervetized in the column oven before the separation into the HPLC column using a Borate buffer and O-phthaldialdeyde (OPA). Elution entailed using three buffers as mobile phases and was detected with a fluorescence detector, at $\mathrm{EX}=348 \mathrm{~nm}$ and $\mathrm{EM}=480 \mathrm{~nm}$ wavelengths. The amino acid compositions in the diets ( $\mathrm{g} / 100 \mathrm{~g}$ diet) are presented in Table 3.

Table 1. Chemical composition of ingredients used in diets formulation fed to Nile tilapia Oreochromis niloticus.

\begin{tabular}{|c|c|c|c|c|c|c|}
\hline & Moisture & Protein & Lipid & Ash & $\mathbf{N F E}^{1}$ & $\begin{array}{c}\text { Gross energy } \\
\text { (Kcal/kg) }^{2}\end{array}$ \\
\hline Fish meal & 8.89 & 67.74 & 10.33 & 20.80 & 1.13 & 485.10 \\
\hline Soybean & 6.84 & 50.12 & 2.91 & 6.77 & 40.20 & 479.52 \\
\hline Yellow corn & 10.60 & 8.80 & 3.10 & 4.40 & 83.70 & 430.56 \\
\hline Wheat bran & 7.00 & 15.81 & 5.25 & 4.55 & 74.39 & 451.35 \\
\hline wheat & 11.20 & 17.58 & 1.40 & 1.59 & 79.43 & 356.18 \\
\hline
\end{tabular}

${ }^{1}$ Nitrogen free extract $(\mathrm{NFE})=100-(\mathrm{CP}+\mathrm{EE}+\mathrm{Ash}) .{ }^{2} \mathrm{Gross}$ energy $(\mathrm{GE})$ was calculated as $5.65,9.45$ and $4.2 \mathrm{Kcal} / \mathrm{g}$ for CP, EE, and NFE, respectively according to Hepher et al., 1983.

Table 2. Proximate composition for experimental diets (g100 $\mathrm{g}^{-1}$ dry weight) fed to Nile tilapia Oreochromis niloticus.

\begin{tabular}{|c|c|c|c|c|c|c|c|}
\hline \multicolumn{8}{|c|}{ Diets } \\
\hline Ingredients & $\begin{array}{c}\text { D1 } \\
\text { (control) }\end{array}$ & $\begin{array}{c}\mathrm{D} 2 \\
(20 \% \mathrm{CP}+\mathrm{AA}) \\
\end{array}$ & $\begin{array}{c}\mathrm{D3} \\
(25 \% \mathrm{CP}+\mathrm{AA}) \\
\end{array}$ & $\begin{array}{c}\text { D4 } \\
(30 \% \mathrm{CP}+\mathrm{AA})\end{array}$ & $\begin{array}{c}\text { D5 } \\
(20 \% \mathrm{CP}) \\
\end{array}$ & $\begin{array}{c}\text { D6 } \\
(25 \% \mathrm{CP}) \\
\end{array}$ & $\begin{array}{c}\text { D7 } \\
(30 \% \mathrm{CP}) \\
\end{array}$ \\
\hline Fish meal & 40 & 3 & 10 & 18 & 3 & 10 & 18 \\
\hline Soybean meal & ---- & 25.00 & 25.00 & 25.00 & 25.00 & 25.00 & 25.00 \\
\hline Wheat meal & 15.00 & 15.00 & 15.00 & 15.00 & 15.00 & 15.00 & 15.00 \\
\hline Wheat bran & 20.00 & 22.00 & 20.00 & 20.00 & 20.00 & 20.00 & 20.00 \\
\hline Yellow corn & 20.00 & 25.00 & 20.00 & 12.00 & 30.00 & 23.00 & 15.00 \\
\hline corn oil & 2.00 & 4.00 & 4.00 & 4.00 & 4.00 & 4.00 & 4.00 \\
\hline Methionine & ---- & 2.00 & 2.00 & 2.00 & ---- & ---- & ---- \\
\hline Lysine & ---- & 1.00 & 1.00 & 1.00 & ---- & ---- & ---- \\
\hline Vitamin $\operatorname{mix}^{1}$ & 2.00 & 2.00 & 2.00 & 2.00 & 2.00 & 2.00 & 2.00 \\
\hline Mineral $\operatorname{mix}^{2}$ & 1.00 & 1.00 & 1.00 & 1.00 & 1.00 & 1.00 & 1.00 \\
\hline \multicolumn{8}{|c|}{ Proximate composition ( $\%$ as fed) } \\
\hline Moisture & 7.61 & 8.21 & 7.98 & 7.71 & 7.92 & 7.88 & 7.21 \\
\hline Protein & 31.85 & 21.85 & 25.40 & 29.72 & 21.89 & 25.67 & 29.99 \\
\hline Lipid & 6.05 & 4.64 & 5.09 & 5.75 & 5.64 & 5.28 & 6.73 \\
\hline Ash & 13.24 & 7.96 & 8.91 & 9.42 & 5.66 & 6.79 & 8.54 \\
\hline $\mathrm{NFE}^{3}$ & 48.40 & 65.55 & 60.60 & 55.11 & 66.87 & 62.26 & 54.74 \\
\hline $\mathrm{GE}(\mathrm{Kcal} / \mathrm{kg})^{4}$ & 443.00 & 442.61 & 446.13 & 453.72 & 457.83 & 456.43 & 462.65 \\
\hline
\end{tabular}

${ }^{1}$ Vitamins mixture contained (as g/kg premix): Thiamine 2.5; Riboflavin2.5; pyridoxine 2.0; Inositol 100.0; Biotin 0.3; Pantothenic acid 100.0; folic acid 0.75; Para-aminobenzioic 2.5; Choline 200.0; Nicotinic acid 10. Cyanocobalmine 0.005; Tocopherol acetate 20.1; Ascorbic acid 50.0; Mena Dione 2.0; Retinol palmitate $100.000 \mathrm{IU}$; Cholecalciferol 500.000 IU. ${ }^{2}$ Mineral premix (as g/kg premix): $\mathrm{CaHPO}_{4} .2 \mathrm{H}_{2} \mathrm{O} 727.7775 ; \mathrm{MgSO}_{4}$. $\mathrm{H}_{2} \mathrm{O} 127.5 ; \mathrm{Kcal} 50.0 ; \mathrm{Na} \mathrm{Cl} 60 ; \mathrm{Fe} \mathrm{SO}_{4} 7 \mathrm{H}_{2} \mathrm{O} 25 ; \mathrm{ZnSO}_{4} .7 \mathrm{H}_{2} \mathrm{O} 505$; $\mathrm{MnSO}_{4} .4 \mathrm{H}_{2} \mathrm{O} 2.53$; $\mathrm{Cu} \mathrm{SO}{ }_{4} 5785 ; \mathrm{CoSO}_{4} 7 \mathrm{H}_{2} \mathrm{O} 0.4775 ; \mathrm{Ca} \mathrm{Lo}_{3} 6 \mathrm{H}_{2} \mathrm{O} .295 ; \mathrm{Cr} \mathrm{CL}_{3} .6 \mathrm{H}_{2} \mathrm{O} 0.1275$. ${ }^{3}$ Nitrogen free extract $(\mathrm{NFE})=100-(\mathrm{CP}+\mathrm{EE}+\mathrm{Ash}) ;{ }^{4} \mathrm{Gross}$ energy $(\mathrm{GE})$ was calculated as $5.65,9.45$ and $4.2 \mathrm{Kcal} / \mathrm{g}$ for CP, EE, and NFE, respectively according to Hepher et al., 1983. 
Table 3. Essential amino acids composition (expressed as percentage of diets) of the control and test diets fed to Oreochromis niloticus and its requirements.

\begin{tabular}{lcccccccc}
\hline & D1 & D2+AA & D3+AA & D4+AA & D5 & D6 & D7 & Requirements* $^{\text {a }}$ \\
\hline Arginine & $2.08 \pm 0.07^{\mathrm{a}}$ & $1.48 \pm 0.06^{\mathrm{d}}$ & $1.66 \pm 0.04^{\mathrm{c}}$ & $1.85 \pm 0.04^{\mathrm{b}}$ & $1.39 \pm 0.07^{\mathrm{d}}$ & $1.77 \pm 0.05^{\mathrm{bc}}$ & $1.83 \pm 0.04^{\mathrm{b}}$ & 1.33 \\
Histidine & $0.97 \pm 0.05^{\mathrm{a}}$ & $0.53 \pm 0.04^{\mathrm{d}}$ & $0.63 \pm 0.04^{\mathrm{c}}$ & $0.83 \pm 0.03^{\mathrm{b}}$ & $0.49 \pm 0.08^{\mathrm{d}}$ & $0.62 \pm 0.04^{\mathrm{c}}$ & $0.76 \pm 0.02^{\mathrm{b}}$ & 0.54 \\
Isoleucine & $1.46 \pm 0.03^{\mathrm{a}}$ & $0.92 \pm 0.06^{\mathrm{c}}$ & $1.18 \pm 0.07^{\mathrm{b}}$ & $1.38 \pm 0.06^{\mathrm{a}}$ & $0.99 \pm 0.03^{\mathrm{c}}$ & $1.14 \pm 0.07^{\mathrm{b}}$ & $1.45 \pm 0.06^{\mathrm{a}}$ & 0.99 \\
Leucine & $2.46 \pm 0.06^{\mathrm{a}}$ & $1.67 \pm 0.10^{\mathrm{d}}$ & $2.08 \pm 0.04^{\mathrm{b}}$ & $2.50 \pm 0.14^{\mathrm{a}}$ & $1.74 \pm 0.07^{\mathrm{d}}$ & $1.93 \pm 0.04^{\mathrm{c}}$ & $2.49 \pm 0.07^{\mathrm{a}}$ & 1.09 \\
Lysine & $2.45 \pm 0.04^{\mathrm{a}}$ & $2.28 \pm 0.02^{\mathrm{bc}}$ & $2.35 \pm 0.03^{\mathrm{b}}$ & $2.46 \pm 0.05^{\mathrm{a}}$ & $2.20 \pm 0.05^{\mathrm{c}}$ & $2.30 \pm 0.02^{\mathrm{b}}$ & $2.35 \pm 0.01^{\mathrm{b}}$ & 1.63 \\
Methionine & $0.74 \pm 0.01^{\mathrm{a}}$ & $0.72 \pm 0.02^{\mathrm{a}}$ & $0.73 \pm 0.03^{\mathrm{a}}$ & $0.72 \pm 0.02^{\mathrm{a}}$ & $0.63 \pm 0.01^{\mathrm{c}}$ & $0.65 \pm 0.02^{\mathrm{b}}$ & $0.67 \pm 0.04^{\mathrm{b}}$ & 1.02 \\
Phenylalanine & $1.41 \pm 0.04^{\mathrm{b}}$ & $0.92 \pm 0.09^{\mathrm{e}}$ & $1.24 \pm 0.04^{\mathrm{c}}$ & $1.59 \pm 0.10^{\mathrm{a}}$ & $1.08 \pm 0.04^{\mathrm{d}}$ & $1.10 \pm 0.07^{\mathrm{d}}$ & $1.55 \pm 0.08^{\mathrm{a}}$ & 1.82 \\
Threonine & $1.56 \pm 0.07^{\mathrm{a}}$ & $1.16 \pm 0.09^{\mathrm{c}}$ & $1.30 \pm 0.08^{\mathrm{b}}$ & $1.38 \pm 0.04^{\mathrm{b}}$ & $1.07 \pm 0.06^{\mathrm{c}}$ & $1.14 \pm 0.08^{\mathrm{c}}$ & $1.28 \pm 0.04^{\mathrm{b}}$ & 1.15 \\
Valine & $1.75 \pm 0.06^{\mathrm{b}}$ & $1.15 \pm 0.08^{\mathrm{e}}$ & $1.51 \pm 0.10^{\mathrm{c}}$ & $1.96 \pm 0.11^{\mathrm{a}}$ & $1.06 \pm 0.05^{\mathrm{e}}$ & $1.34 \pm 0.07^{\mathrm{d}}$ & $1.64 \pm 0.09^{\mathrm{bc}}$ & 1.09 \\
Tryptophan & $\mathrm{ND}$ & $\mathrm{ND}$ & $\mathrm{ND}$ & $\mathrm{ND}$ & $\mathrm{ND}$ & $\mathrm{ND}$ & $\mathrm{ND}$ &
\end{tabular}

*From Santiago and Lovell (1988).

\section{Statistical Analysis}

The data were analysed statistically by using one-way analysis of variance (ANOVA) technique and the means were compared using the Duncan's Multiple Range Test (DMRT) as described by Snedecor and Cochran (1989).

\section{Results}

\subsection{Biochemical composition of diets}

The experimental diets contained different levels of protein ranging between $20-30 \%$ with and without amino acid supplementation (Table 2). The dietary AAs shown in Table 3 indicate that almost all the AAs were highest in D1 except Lysine in D4 and D7 which were slightly higher than D1; Phenylalanine was higher again in D4 and D7; and Valine in D4, which contained a high amount of fishmeal with significant differences $(\mathrm{P}>0.05)$ compared to other diets. Diets containing plant source protein and AAs (D2, D3, and D4) showed slightly higher levels of some amino acids than the other three diets (D5, D6, and D7), especially of lysine and methionine, which showed significantly higher values. However, most of the dietary amino acid contents were affected in diets excluding AAs.

\subsection{Growth performance}

The growth performance and feed utilization results for the $O$. niloticus fed on the seven diets are presented in Table 4. No mortality was recorded during the study period. A significant difference $(\mathrm{P}<0.05)$ was observed for the final average body weight and length for fish fed with D1 (control diet), D2, D3, D5, and D7. The fish fed with diet D4 and D7 exhibited non-significant difference with each other. The highest mean body weight was recorded as 42.46, 39.97 and 38.33g in fish fed the fishmeal-based control diet (D1), and those with the highest levels of dietary protein (D4 and D7), respectively, compared with the other four diets (D2, D3, D5, and D6) that contained 20 and $25 \%$ of protein with and without AAs supplementation (Table 4). These fish were weighed at $30.64,35.59,27.45$ and $29.42 \mathrm{~g}$ respectively. Following the same pattern, the results of final body length ranged between 13.32 and $11.46 \mathrm{~cm}$ (Table 4). The specific growth rate $(\mathrm{SGR} \%$ ) results further substantiated this trends, with high SGR for D1, D4, and D7, that is, 1.42, 1.37 and 1.42\% respectively. SGR values for D2, D3, D5, and D6 were $1.05,1.19,0.88$, and $1.10 \%$, respectively, with significant differences $(\mathrm{P}<0.05)$ between all groups except $\mathrm{D} 5$ which fed $20 \%$ protein without AAs (Table 4 ). Weight gain also was significantly higher in D1, D4, and D7 compared with other groups (Table 4).

\subsection{Feed consumption and feed utilization}

The experimental feeds (D1, D3, D4, and D7) were well accepted by $O$. niloticus, except fish fed with diets D2, D5 and D6, which contained $20 \%$ protein+AAs, and 20 and $25 \%$ protein without amino acid, respectively. These diets resulted in a total feed intake per fish of 45.50, 39.98 and $39.03 \mathrm{~g}$, which were significantly lower $(\mathrm{P}<0.05)$ compared to $48.21,47.76,48.34$ and $48.00 \mathrm{~g}$ for feeds D1, D3, D4, and D7, respectively (Table 4). Feed intake for $O$. niloticus fed on the D1 (control diet) having the highest amount of fishmeal, D4 and D7 which contained $30 \%$ of protein with and without AAs supplementation performed better compared to other diets. The best FCR values were 1.63, 1.77, and 1.80 for D1, D4, and D7, compared to 2.53, 2.12, 2.78, and 2.20 for D2, D3, D5, and D6, respectively. The protein efficiency ratio (PER) was noticeably different between treatments and followed the similar pattern, where the fish fed with D1 had better PER (1.93) followed by D3, D4, and D7 (1.86, 1.90, and 1.85, respectively) with insignificant differences between the groups. Protein productive values (PPV \%) values also showed a decrease when fish were fed diets containing 20\%+AAs, and 20, 25, and 30\% protein without AA supplementation in group fed with D1, D3, D4 with a significant difference $(\mathrm{P}<0.05)$ between treatments (Table 4).

\subsection{Fish body composition}

The initial and final proximate composition of the fish fed with the experimental diets is presented in Table 5 . The final proximate composition in $O$. niloticus exhibited 
Table 4. Weight increase, feed consumption, nutritive utilization of Oreochromis niloticus fed experimental diets (mean $\pm \mathrm{SD} n=3$ ).

\begin{tabular}{|c|c|c|c|c|c|c|c|}
\hline & $\begin{array}{c}\text { D1 } \\
\text { (control) }\end{array}$ & $\begin{array}{c}\text { D2 } \\
(20 \% \mathrm{CPV}+\mathrm{AA}) \\
\end{array}$ & $\begin{array}{c}\mathrm{D3} \\
(25 \% \mathrm{CP}+\mathrm{AA}) \\
\end{array}$ & $\begin{array}{c}\mathrm{D} 4 \\
(30 \% \mathrm{CP}+\mathrm{AA}) \\
\end{array}$ & $\begin{array}{c}\text { D5 } \\
(20 \% \mathrm{CP}) \\
\end{array}$ & $\begin{array}{c}\text { D6 } \\
(25 \% \mathrm{CP}) \\
\end{array}$ & $\begin{array}{c}\text { D7 } \\
(30 \% \mathrm{CP}) \\
\end{array}$ \\
\hline $\begin{array}{l}\text { Mean initial } \\
\text { weight }(\mathrm{g})\end{array}$ & $12.94 \pm 2.16$ & $12.65 \pm 1.12$ & $13.06 \pm 1.18$ & $12.66 \pm 0.93$ & $13.07 \pm 0.75$ & $11.65 \pm 1.49$ & $11.64 \pm 1.37$ \\
\hline $\begin{array}{l}\text { Mean final } \\
\text { weight }(\mathrm{g})\end{array}$ & $42.46 \pm 3.98^{\mathrm{a}}$ & $30.64 \pm$ & $35.59 \pm 1.58^{\mathrm{b}}$ & $39.97 \pm 1.65^{\mathrm{ab}}$ & $27.45 \pm 1.18^{\mathrm{c}}$ & $29.42 \pm 1.16^{\mathrm{c}}$ & 38.33 \\
\hline $\begin{array}{l}\text { Mean initial } \\
\text { length }(\mathrm{cm})\end{array}$ & $9.40 \pm 0.71$ & $9.01 \pm 0.38$ & $9.32 \pm 0.31$ & $9.29 \pm 0.30$ & $9.33 \pm 0.28$ & $8.82 \pm 0.36$ & $8.75 \pm 0.38$ \\
\hline $\begin{array}{l}\text { Mean final } \\
\text { length }(\mathrm{cm})\end{array}$ & $13.32 \pm 1.93^{\mathrm{a}}$ & $11.66 \pm 1.28^{\mathrm{c}}$ & $12.45 \pm 1.39^{b}$ & $12.92 \pm 1.64^{\mathrm{ab}}$ & $11.58 \pm 0.92^{\mathrm{c}}$ & $11.46 \pm 1.21^{\mathrm{c}}$ & $12.19 \pm 1.67^{b c}$ \\
\hline Weight gain $(\mathrm{g})$ & $29.53 \pm 0.55^{\mathrm{a}}$ & $17.99 \pm 0.06^{\mathrm{d}}$ & $22.53 \pm 0.61^{\mathrm{c}}$ & $27.31 \pm 1.57^{\mathrm{ab}}$ & $14.38 \pm 0.62^{\mathrm{e}}$ & $17.77 \pm 0.15^{\mathrm{d}}$ & $26.69 \pm 0.14^{b}$ \\
\hline SGR $\%{ }^{1}$ & $1.42 \pm 0.13^{\mathrm{a}}$ & $1.05 \pm 0.13^{\mathrm{ab}}$ & $1.19 \pm 0.15^{\mathrm{ab}}$ & $1.37 \pm 0.14^{\mathrm{a}}$ & $0.88 \pm 0.13^{b}$ & $1.10 \pm 0.16^{\mathrm{ab}}$ & $1.42 \pm 0.17^{\mathrm{a}}$ \\
\hline $\begin{array}{l}\text { Percentage of } \\
\text { WG } \%\end{array}$ & $228.23 \pm 2.85^{\mathrm{a}}$ & $142.17 \pm 4.31^{\mathrm{c}}$ & $172.55 \pm 4.29^{b}$ & $215.79 \pm 4.02^{\mathrm{a}}$ & $110.00 \pm 6.28^{\mathrm{d}} 1$ & $52.57 \pm 0.41^{\mathrm{bc}}$ & $229.28 \pm 1.30^{\mathrm{a}}$ \\
\hline FI g/fish & $48.21 \pm 1.68^{\mathrm{a}}$ & $45.50 \pm 1.71^{\mathrm{b}}$ & $47.76 \pm 1.73^{\mathrm{a}}$ & $48.34 \pm 1.39^{\mathrm{a}}$ & $39.98 \pm 1.33^{\mathrm{c}}$ & $39.03 \pm 1.16^{c}$ & $48.00 \pm 1.08^{\mathrm{a}}$ \\
\hline $\mathrm{FCR}^{2}$ & $1.63 \pm 0.18^{c}$ & $2.53 \pm 0.27^{\mathrm{ab}}$ & $2.12 \pm 0.27^{\mathrm{bc}}$ & $1.77 \pm 0.17^{\mathrm{c}}$ & $2.78 \pm 0.25^{\mathrm{a}}$ & $2.20 \pm 0.48^{\mathrm{bc}}$ & $1.80 \pm 0.13^{\mathrm{c}}$ \\
\hline $\mathrm{PER}^{3}$ & $1.93 \pm 0.35^{\mathrm{a}}$ & $1.81 \pm 0.30^{\mathrm{a}}$ & $1.86 \pm 0.35^{\mathrm{a}}$ & $1.90 \pm 0.27^{\mathrm{a}}$ & $1.65 \pm 0.30^{\mathrm{a}}$ & $1.77 \pm 0.35^{\mathrm{a}}$ & $1.85 \pm 0.27^{\mathrm{a}}$ \\
\hline PPV $(\%)^{4}$ & $24.54 \pm 1.53^{\mathrm{a}}$ & $17.81 \pm 1.20^{\mathrm{b}}$ & $23.58 \pm 1.00^{\mathrm{a}}$ & $25.68 \pm 1.62^{\mathrm{a}}$ & $8.81 \pm 1.53^{\mathrm{d}}$ & $12.68 \pm 1.70^{c}$ & $16.25 \pm 1.18^{\mathrm{b}}$ \\
\hline
\end{tabular}

Values in the same row with the same superscript (a-d) are not significantly different $(\mathrm{P}>0.05)$. ${ }^{1}$ SGR: [Ln final body weight (g) - Ln initial body weight $(\mathrm{g})]$ /experimental period (days) $\times 100 .{ }^{2} \mathrm{FCR}$ : feed intake $(\mathrm{g}) /$ body weight gain $(\mathrm{g}) .{ }^{3} \mathrm{PER}$ : body weight gain $(\mathrm{g}) /$ protein intake $(\mathrm{g}) .{ }^{4} \mathrm{PPV}(\%)$ : retained protein $(\mathrm{g}) /$ total protein intake $(\mathrm{g}) \times 100$.

Table 5. Body composition of Nile tilapia fed diets with and without amino acids supplementation.

\begin{tabular}{|c|c|c|c|c|c|c|c|c|}
\hline Par & 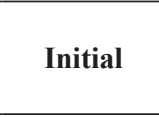 & $\begin{array}{c}\text { D1 } \\
\text { (control }\end{array}$ & $\begin{array}{c}\text { D2 } \\
(20 \% \mathrm{CP} \\
+\mathrm{AA}) \\
\end{array}$ & $\begin{array}{c}\text { D3 } \\
(25 \% \mathrm{CP} \\
+\mathrm{AA}) \\
\end{array}$ & $\begin{array}{c}\mathrm{D} 4 \\
(30 \% \mathrm{CP} \\
+\mathrm{AA}) \\
\end{array}$ & $\begin{array}{c}\text { D5 } \\
(20 \% \mathrm{CP})\end{array}$ & $\begin{array}{c}\text { D6 } \\
(25 \% \mathrm{CP})\end{array}$ & $\begin{array}{c}\text { D7 } \\
(\mathbf{3 0 \%} \mathrm{CP})\end{array}$ \\
\hline & & & $25+$ & $75.23 \pm 0.63^{\text {bc }}$ & $74.57 \pm 0$ & & & \\
\hline Prot & 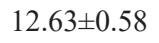 & $5^{\mathrm{a}}$ & $14.40 \pm$ & $0^{\mathrm{a}}$ & 16.3 & 1 & 13.90 & $20^{\mathrm{a}}$ \\
\hline Lip & 13 & $65 \mathrm{a}$ & $2.99 \pm 0.52^{\mathrm{bc}}$ & $3.61 \pm 0.65^{\mathrm{abc}}$ & $2.85 \pm 0.62^{\mathrm{c}}$ & $4.39 \pm 0.52^{\mathrm{abc}}$ & $3.88 \pm 0.59^{\mathrm{abc}}$ & $4.66 \pm 0.44^{\mathrm{ab}}$ \\
\hline b & $.47 \pm 0.11$ & $4.27 \pm 0.13^{\mathrm{ab}}$ & $3.46 \pm 0.13^{\mathrm{c}}$ & $4.03 \pm 0.08^{b}$ & $4.02 \pm 0.10^{\mathrm{b}}$ & $4.12 \pm 0.10^{\mathrm{ab}}$ & $4.26 \pm 0.07^{\mathrm{ab}}$ & $4.25 \pm 0.10^{\mathrm{at}}$ \\
\hline
\end{tabular}

Values in the same row with the same superscript $(\mathrm{a}-\mathrm{c})$ are not significantly different $(\mathrm{P}>0.05)$. Values expressed as mean $\pm \mathrm{SE}(\mathrm{n}=3)$.

significant $(\mathrm{P}<0.05)$ variation in different constituents for different experimental diets. Fish fed with the fishmeal-based control diet D1, and diets D3, D4, and D7 showed a significant elevation in carcass protein with a protein content of $16.40,15.49,16.32$, and 14.97 respectively compared with other the D2, D5 and D6 diets with values of 14.40, 13.40 and 13.90, respectively. Whole body lipid content showed significant differences between treatment, with the significantly highest lipid content observed in fish fed D1, D5, and D7 compared to other treatments. A significantly higher ash content occurred in fish fed with the diets D1, D5, D6, and D7 $(\mathrm{P}<0.05)$, it was lower in diets D2, D3 and D4 respectively. In contrast, fish fed diets with amino acids supplementation showed a decrease in moisture, lipid and ash contents (Table 5).

\subsection{Economic evaluation}

The results in Table 6 provide an economic evaluation of the experimental diets, including feed costs, costs per one $\mathrm{kg}$ weight gain, and the ratio compared to the control diet. The costs of $1 \mathrm{~kg}$ of the control diet and other tested diets were $1.23,0.53,0.69,0.87,0.52,0.67$, and 0.86 US
Dollar for D1, D2, D3, D4, D5, D6, and D7, respectively. These results indicated that a reduction in the use of fishmeal in tilapia diets reduced the price of $1 \mathrm{~kg}$ of those diets to $43.09,56.10,70.73,42.28,54.47$, and $69.92 \%$ of the control diet. The costs required to produce one $\mathrm{kg}$ of weight gain were the highest for the control diet and gradually decreased to $66.66,72.64$ and 73.63 percent for D2, D3, and D4 (i.e. the diets containing AA supplementation) and $72.14,73.13$, and $77.11 \%$ for D5, D6, and D7 that did not have AA supplementation (Table 6). The minimum cost of production was found in fish fed with D2.

\section{Discussion}

The results of this study show that the different protein levels of the experimental feeds noticeably affected the growth performance and feed utilization of Nile tilapia. Most of the AAs determined in the diets were relatively higher than the minimum requirement for AAs in Nile tilapia (Santiago and Lovell, 1988) except methionine and phenylalanine. The findings of this study indicated that the best dietary protein requirement for $O$. niloticus depends 
Table 6. Feed costs (US\$) for producing one kg weight by fish fed the experimental diets.

\begin{tabular}{lcrrrrrr}
\hline & D1 & D2+AA & D3+AA & D4+AA & \multicolumn{1}{c}{ D5 } & \multicolumn{1}{c}{ D6 } & D7 \\
\hline feed cost (US\$/Kg) & 1.23 & 0.53 & 0.69 & 0.87 & 0.52 & 0.67 & 0.86 \\
Relative to control \% & 100 & 43.09 & 56.10 & 70.73 & 42.28 & 54.47 & 69.92 \\
Decrease in feed costs \% & 0.00 & 56.91 & 43.90 & 29.27 & 57.72 & 45.53 & 30.08 \\
FCR & 1.63 & 2.53 & 2.12 & 1.77 & 2.78 & 2.20 & 1.80 \\
Feed cost (US\$/Kg WG*) & 2.01 & 1.34 & 1.46 & 1.48 & 1.45 & 1.47 & 1.55 \\
Relative to control \% & 100 & 66.66 & 72.64 & 73.63 & 72.14 & 73.13 & 77.11 \\
\hline
\end{tabular}

The price of $1 \mathrm{~kg}$ ingredients used was 9.2 Saudi Riyals (SR) for fish meal,1.6 soybean, 0.7 for wheat bran, 0.8 for Wheat meal, 0.75 for yellow corn, 12.00 for corn oil, 2.60 for methionine, 1.5 for lysine and 10.00 for vitamin and minerals mix according to market price at the time of study (2014). All prices were converted to US\$ which equal $3.75 \mathrm{SR}$. *Feed costs $/ 1 \mathrm{~kg}$ weight gain $=$ FCR $\times$ costs of $\mathrm{kg}$ feed.

on fish weight. In this study, the initial weight of the fish was $12 \mathrm{~g}$, meaning that our data was in agreement with Khattab et al. (2000) who reported the best dietary protein level for three $O$. niloticus strains of the similar weight group and noted that the optimum level of dietary protein ranged between 27 and $37 \%$. The results of this study observed that plant protein sources are unable to replace $3 \mathrm{~g} / 100 \mathrm{~g}$ of diets (see Table 2) which equated to about $10 \%$ of the total protein fishmeal in diets, especially D2 and D5 that contained less protein than the requirement $(20 \%$ with or without AAs) for O. niloticus (El-Sayed, 2006). Growth and feed utilization were, also, reduced in fish fed with diets D3 and D6, which include (10g/100g diet) in which fishmeal was replaced with vegetable protein sources these might be the ration of replaced is high about $75 \%$ of total protein from plant ingredients, these diets contain AAs lower than the minimum requirements of this fish especially without methionine in D6 (Table 2). The addition of AAs enhances the growth and feed utilization for fish fed D3 which has the same protein level but with AAs supplementation. The present findings were in accordance with results illustrated by Santigosa et al. (2008) who observed that substitution of fish meal by vegetable proteins led to a reduction in fish weight in Oncorhynchus mykiss and sea bream Sparusaurata. O. niloticus fed with diets D4 and D7 (30\% protein) with and without AA supplementation, showed excellent final body weight with no significant difference when compared to the control. The current study, therefore, serves to recommend that supplemented amino acids might not be efficiently utilized by Nile tilapia fed diets with low protein levels and high amount of plant protein sources.

The decrease in fishmeal content from $40 \mathrm{~g} / 100 \mathrm{~g}$ to $3 \mathrm{~g} / 100 \mathrm{~g}$ in the diets by progressively increasing the extent of replacement with mixed plant protein in gilthead sea bream and tilapia diets reduced the efficiency of digestive enzymes and effected on growth performances (Kokou et al., 2016; Abdel-Warrith et al., 2013). In this study the experimental diets showed a significant effect on the growth performance of Nile tilapia. These outcomes are in line with results reported by Pratoomyot et al. (2010) who observed that when the fishmeal content of the diet was reduced from $25 \%$ to $5 \%$ there was a decrease in growth performance and thus in body weight among Atlantic salmon Salmo salar. Moreover, in our study, growth parameters such as SGR were enhanced by increasing protein level and AA supplementation in the dietThese results were in agreement with results obtained by Pratoomyot et al. (2010) who reported that SGR for Salmo salar fed diets containing 18,11 and $5 \%$ of fishmeal decreased compared to control diet $(25 \%$ fishmeal). The tilapia fed the control $32 \%$ fishmeal and $30 \%$ with and without AAs for D1, D4, and D7, respectively showed a better weight gain. Our findings were in accord with the findings of Pratoomyot et al. (2008, 2010).

Methionine and lysine addition did not improve the increase in fish weight and length for diets containing $20 \%$ protein compared to other two diets with 25 and $30 \%$ protein. The amount of amino acids like methionine supplementation in D2 was insufficient (lower than the requirements, as listed in Table 3). This may, in turn, be due to D2 and D5 having low amounts of fishmeal which effect on the amino acids content in diet composition. This was in line with findings of Pratoomyot et al. (2010) who found that increasing alternatives to fishmeal in the form of plant protein in diets for Salmo salar caused a decrease growth performance that was due to reduced palatability. This is also compatible with other previous studies (Davies and Morris 1997; Kaushik et al., 2004; Espe et al., 2006; Abdel-Warrith et al., 2013).

The growth performance of $O$. niloticus fed diets containing AAs with a protein level of $25 \%$ declined in relation to any of the $30 \%$ protein diets. Our study was incompatible with this previous data (Yamamoto et al., 2005). although the individual AA requirements were sufficient except for methionine, which was lower than requirements for Nile tilapia test diets. The methionine concentration in the experimental diets ranged between $0.63 \%-0.74 \%$ of the feed, being lower in diet D1, D2, D3 and D4 (control and the other three diets supplemented by methionine), but still less than the requirements for all test diets and lower than $1.02 \%$ of protein. These results were in agreement with findings of Koch et al. (2016) with respect to the same species of fish. Diógenes et al. (2016) reported that the contents of methionine in the best growth performing substitutent diet was slightly higher than the optimum methionine level for O. niloticus (Botaro et al., 2007; Michelato et al., 2013, 2016). On the other hand, the 
concentration of methionine was lower than this requirement in most of the other test diets.

Variations in protein utilization parameters, such as PER and PPV were affected by the treatments. These parameters were significantly $(\mathrm{P}>0.05)$ affected by protein content and AA supplementation in the diets. Protein metabolism increased with increase in dietary protein levels and AA supplementation. It might be because a major part of weight increase is related to the protein retention, and protein increases establish equilibrium between protein anabolism and catabolism (Diogenes et al.,2016). Abdel-Tawwab et al. (2010) reported that protein metabolism, including PER, PPV, and PGR, were significantly $(\mathrm{P}>0.05)$ affected by protein levels in the diets. Moreover, feed efficiency was significantly affected by protein content and AA supplementation, FCR improved with fish fed diets containing high protein levels and AAs supplementation as previously shown in respect to the Nile tilapia (Abdelghany, 2000; Khattab et al., 2000).

The proximate composition of the carcasses of the fish was significantly affected by dietary protein level, and AA supplementation of the fish fed diets containing high amounts of protein showed high values of protein in their body composition. This was in line with results obtained by Abdel-Tawwab et al. (2010) who demonstrated that Nile tilapia fed a 25\%-CP diet had lower protein values and higher lipid content than fish fed $35 \%$ - or $45 \%$-CP diets. This might be related to the high feed consumption, feed utilization, and the high nutrient digestibility as the accumulated nutrients increased in the experimental diets. Furuya et al. (2004) mentioned that dietary amino acid supplementation caused an increase in protein and decreased the lipid in the fish body. The variations in lysine requirement within and among species have been observed in several publications. The variations in amino acids supplementation may be a result of nutrient utilization, different basal diets, different feeding levels and environmental conditions, the age of fish and species or strains.

In this study, all diets other than the control diet were different from commercial diets in terms of cost because it's containing less amount of fishmeal. Therefore, the growth performance for tilapia was significantly lower than the control except for D4 and D7, which were insignificantly different in terms of growth performance and feed utilization compared to the control, which saves about $30 \%$ of feed costs (US\$) for producing one $\mathrm{kg}$ of additional weight. Furthermore, the amino acid supplementation improved the economic evaluation in tilapia diets. Most studies have evaluated fishmeal substitution in tilapia feeds from biological and nutritional standpoints. A very little attention has been paid to the cost analysis of these dietary sources but the few investigations in this area have indicated that the unusual or plant protein sources were more economical compared with fishmeal.

\section{Conclusion}

It can be concluded that $O$. niloticus are able to utilize plant protein-based diets with mixed sources (soybean, yellow corn, wheat meal and wheat bran) that covered about $60 \%$ of total protein (D4 and D7) with and without amino acids supplementation. Growth and feed utilization were much lower than in the fish fed the control diet except for the D4 and D7 groups which contained 30\% protein, with and without methionine and lysine supplementation, respectively. The economic evaluation conducted in this study saved about $30 \%$ of feed costs for producing one $\mathrm{kg}$ weight. Future studies should, therefore, consider the use of these ingredients with supplementation of high amounts of amino acids.

\section{Acknowledgements}

The authors would like to extend their sincere appreciation to the Deanship of Scientific Research at King Saud University for the funding of this research through the Research Group Project No. RGP-VPP-304.

\section{References}

ABDELGHANY, A.E. 2000. Optimum dietary protein requirements for Oreochromis niloticusL. fry using formulated semi-purified diets. In: K. FITZSIMMONS and J.C. FILHO, eds. Tilapia Aquaculture in the 21st Century. Rio de Janeiro: Proceedings from the 5th International Symposium on Tilapia Aquaculture, vol. 1, pp. 101-108.

ABDEL-TAWWAB, M., AHMAD, M.H., KHATTAB, Y.A.E. and SHALABY, A.M.E., 2010. Effect of dietary protein level, initial body weight, and their interaction on the growth, feed utilization, and physiological alterations of Nile tilapia, Oreochromis niloticus (L.). Aquaculture, vol. 298, no. 3-4, pp. 267-274. http://dx.doi. org/10.1016/j.aquaculture.2009.10.027.

ABDEL-WARRITH, A.A., YOUNIS, E.M. and AL-ASGAH, N.A., 2013. Influence of dietary inclusion of full-fat soybean meal and amino acids supplementation on growth and digestive enzymes activity of Nile Tilapia, Oreochromis niloticus. Turkish Journal of Fisheries and Aquatic Sciences, vol. 13, no. 1, pp. 6977. http://dx.doi.org/10.4194/1303-2712-v13_1_09.

ASSOCIATION OF OFFICIAL ANALYTICAL CHEMISTS AOAC, 1995. Official methods of analysis. 16th ed. Washington, DC: AOAC.

AYISI, C.L., ZHAOI, J. and RUPIA, E.J., 2017. Growth performance, feed utilization, body and fatty acid composition of Nile tilapia (Oreochromis niloticus) fed diets containing elevated levels of palm oil[J]. Aquaculture and Fisheries, vol. 2 , no. 2, pp. 67-77.

BOTARO, D., FURUYA, W.M., SILVA, L.C.R., SANTOS, L.D., SILVA, T.S.C., SANTOS, V.G., 2007. Redução da proteína da dieta com base no conceito de proteína ideal paratilápiasdonilo (Oreochromis niloticus) criada sem tanques-rede. Revista Brasileira de Zootecnia, vol. 36, no. 3, pp. 517-525. http://dx.doi. org/10.1590/S1516-35982007000300001.

DAVIES, S.J. and MORRIS, P.C., 1997. Influence of multiple amino acids supplementation on the performance of rainbow trout. Oncorhynchus mykiss (Walbaum), fed soya based diets. Aquaculture Research, vol. 28, no. 1, pp. 65-74. http://dx.doi. org/10.1111/j.1365-2109.1997.tb01316.x.

DHWAN, A. and KAUR, S., 2002. Pig dung as pond manure: effect on water quality, pond productivity and growth of carps 
in polyculture system. Naga, the ICLARM Quarterly, vol. 25, no. 1, pp. 11-14

DIOGENES, A.F., FERNANDES, J.B.K., DORIGAM, J.C.P., SAKOMURA, N.K., RODRIGUES, F.H.F., LIMA, B.T.M. and GONÇALVES, F.H., 2016. Establishing the optimal essential amino acid ratios in juveniles of Nile tilapia (Oreochromis niloticus) by the deletion method. Aquaculture Nutrition, vol. 22, no. 2, pp. 435-443. http://dx.doi.org/10.1111/anu.12262.

EL-SAIDY, D.M.S. and GABER, M.M.A., 2003. Replacement of fish meal with a mixture of different plant protein sources in juvenile Nile tilapia, Oreochromis niloticus (L.) diets. Aquaculture Research, vol. 34, no. 13, pp. 1119-1127. http:// dx.doi.org/10.1046/j.1365-2109.2003.00914.x.

EL-SAYED, A.F.M., 1999. Alternative dietary protein sources for farmed tilapia, Oreochromis spp. Aquaculture (Amsterdam, Netherlands), vol. 179, no. 1-4, pp. 149-168. http://dx.doi. org/10.1016/S0044-8486(99)00159-3.

EL-SAYED, A.F.M., 2006. Tilapia culture. United Kingdom: CABI Publishing.

EL-SAYED, A.F.M., 2014. Is dietary taurine supplementation beneficial for farmed fish and shrimp? A comprehensive review. Reviews in Aquaculture, vol. 6, no. 4, pp. 241-255. http://dx.doi. org/10.1111/raq.12042.

ESPE, M., LEMME, A., PETRI, A. and EL-MOWAFIA, A., 2006. Can Atlantic salmon grow on diets devoid of fish meal? Aquaculture, vol. 255, no. 1-4, pp. 255-262. http://dx.doi. org/10.1016/j.aquaculture.2005.12.030.

ESPE, M., LEMME, A., PETRI, A. and EL-MOWAFI, A., 2007. Assessment of lysine requirement for maximal protein accretion in Atlantic salmon using plant protein diets. Aquaculture, vol. 263, no. 1-4, pp. 168-178. http://dx.doi.org/10.1016/j. aquaculture.2006.10.018

FOOD AND AGRICULTURE ORGANIZATION OF THE UNITED NATIONS -FAO, 2004. FAO Fish Stat plus. Aquaculture Production 1970-2002. Rome: FAO.

FURUYA, W.M., PEZZATO, L.E., BARROS, M.M., PEZZATO, A.C., FURUYA, V.R.B and MIRANDA, E.C., 2004. Use of ideal protein concept for precision formulation of amino acid levels in fish-meal free diets for juvenile Nile tilapia (Oreochromis niloticus L.). Aquaculture Research, vol. 35, pp. 1110-1116.

GOMES, E.F., REMA, P. and KAUSHIK, S.J., 1995. Replacement of fishmeal by plant proteins in the diet of rainbow trout (Oncorhynchus mykiss): digestibility and growth performance. Aquaculture, vol. 130, no. 2-3, pp. 177-186. http://dx.doi. org/10.1016/0044-8486(94)00211-6.

GONZALES JÚNIOR, J.M., HUTSON, A.H., ROSINSKI, M.E., WU, Y.V., POWLESS, T.F. and BROWN, P.B., 2007. Evaluation of fish meal-free diets for first feeding Nile tilapia, Oreochromis niloticus. Journal of Applied Aquaculture, vol. 19, no. 3, pp. 89-99. http://dx.doi.org/10.1300/J028v19n03_06.

GUO, Z., ZHU, X., LIU, J., HAN, D., YANG, Y., LAN, Z. and XIE, S., 2012. Effects of dietary protein level on growth performance, nitrogen and energy budget of juvenile hybrid sturgeon, Acipenser baerii $\bigcirc \times$. gueldenstaedtii $\widehat{O}$. Aquaculture, vol. 338-341, pp. 89-95. http://dx.doi.org/10.1016/j.aquaculture.2012.01.008.

HEPHER, B., LIAO, V., CHANG, S.H. and HSIEH, C.S., 1983. Food utilization by red tilapia effect of diet composition, feeding level and temperature on utilization efficiencies for maintenance and growth. Aquaculture, vol. 3 pp. 255-275. http:// doi:10.1016/0044-8486(83)90223-5.

KAUSHIK, S.J., COVES, D., DUTTO, G. and BLANC, D., 2004. Almost total replacement of fish meal by plant protein sources in the diet of a marine teleost, the European sea bass, Dicentrarchuslabrax. Aquaculture, vol. 230, no. 1-4, pp. 391-404. http://dx.doi.org/10.1016/S0044-8486(03)00422-8.

KHATTAB, Y.A.E., AHMAD, M.H., SHALABY, A.M.E. and ABDEL-TAWWAB, M. 2000. Response of Nile tilapia (Oreochromis niloticus L.) from different locations to different dietary protein levels. Egyptian Journal Aquaculture Biology Fish, vol. 4, pp. 295-311.

KOCH, J.F., RAWLES, S.D., WEBSTER, C.D., CUMMINS, V., KOBAYASHI, Y., THOMPSON, K.R., GANNAMD, A.L., TWIBELL, R.G. and HYDE, N.M., 2016. Optimizing fish mealfree commercial diets for Nile tilapia, Oreochromis niloticus. Aquaculture, vol. 452, pp. 357-366.

KOKOU, F., RIGOS, G., KENTOURI, M. and ALEXIS, M., 2016. Effect of DL-methionine-supplemented dietary soy protein concentrate on growth performance and intestinal enzyme activity of gilthead sea bream (Sparusaurata L.). Aquaculture International, vol. 24, no. 1, pp. 257-271. http://dx.doi.org/10.1007/ s10499-015-9923-6.

LIM, C., GARCIA, J.C., YILDIRIM-AKSOY, M., KLESIUS, P.H., SHOEMAKER, C.A. and EVANS, J.J., 2007. Growth response and resistance to Streptococcus iniae of Nile tilapia, Oreochromis niloticus, fed diets containing distiller's dried grains with soluble. Journal of the World Aquaculture Society, vol. 38, no. 2, pp. 231-237. http://dx.doi.org/10.1111/j.17497345.2007.00093.x.

LIU, X., JIN, C., WU, L., et 1.., 2017. Hic74, a novel alanine and glycine rich matrix protein related to nacreous layer formation in the mollusc Hyriopsis cumingii[J]. Aquaculture and Fisheries, vol. 2, no. 3, pp. 119-123.

MICHELATO, M., FURUYA, W.M., GRACIANO, T.S., VIDAL, L.V.O., XAVIER, T.O., MOURA, L.B. and FURUYA, V.R.B., 2013. Digestible methionine+cystine requirement for Nile tilapia from 550 to $700 \mathrm{~g}$. Brazilian Journal of Animal Science, vol. 42 , no. 1 , pp. 7-12.

MICHELATO, M., VIDAL, L.V.O., XAVIER, T.O., GRACIANO, T.S.; MOURA, L.B.; FURUYA, V.R.B. and FURUYA, W.M., 2016. Dietary threonine requirement to optimize protein retention and fillet production of fast growing Nile tilapia. Aquaculture Nutrition, vol. 22, pp. 759-766.

MONTANHINI NETO, R. and OSTRENSKY,A., 2015. Evaluation of commercial feeds intended for the Brazilian production of Nile tilapia (Oreochromisniloticus L.): nutritional and environmental implications. Aquaculture Nutrition, vol. 21, no. 3, pp. 311-320. http://dx.doi.org/10.1111/anu.12154.

NAYLOR, R.L., GOLDBURG, R.J., PRIMAVERA, J.H., KAUTSKY, N., BEVERIDGE, M.C., CLAY, J., FOLKE, C., LUBCHENCO, J., MOONEY, H. and TROELL, M., 2000. Effect of aquaculture on world fish supplies. Nature, vol. 405, no. 6790, pp. 1017-1024. http://dx.doi.org/10.1038/35016500. PMid: 10890435 .

PRATOOMYOT, J., BENDIKSEN, E.A., BELL, J.G. and TOCHER, D.R., 2008. Comparison of effects of vegetable oils blended with southern hemisphere fish oil and decontaminated northern hemisphere fish oil on growth performance, composition and gene expression in Atlantic salmon (Salmo salar L.). 
Aquaculture, vol. 280, no. 1-4, pp. 170-178. http://dx.doi. org/10.1016/j.aquaculture.2008.04.028.

PRATOOMYOT, J., BENDIKSEN, E.A., BELL, J.G. and TOCHER, D.R., 2010. Effects of increasing replacement of dietary fishmeal with plant protein sources on growth performance and body lipid composition of Atlantic salmon (Salmo salar L.). Aquaculture, vol. 305, no. 1-4, pp. 124-132. http://dx.doi. org/10.1016/j.aquaculture.2010.04.019.

SANTIAGO, C.B. and LOVELL, R.T., 1988. Amino acid requirements for growth of Nile tilapia. The Journal of Nutrition, vol. 118, no. 12, pp. 1540-1546. http://dx.doi.org/10.1093/ jn/118.12.1540. PMid:3210083.

SANTIGOSA, E., SANCHEZ, J., MEDALE, F., KAUSHIK, S., PÉREZ-SÁNCHEZ, J. and GALLARDO, M.A., 2008. Modifications of digestive enzymes in trout (Oncorhynchus mykiss) and sea bream (Sparus aurata) in response to dietary fish meal replacement by plant protein sources. Aquaculture, vol. 282, no. 1-4, pp. 68-74. http://dx.doi.org/10.1016/j.aquaculture.2008.06.007.

SNEDECOR, G.W. and COCHRAN, W.G., 1989. Statistical methods. Ames: The Iowa State University Press, 476 p.
WEBSTER, C.D., TIU, L.G., MORGAN, A.M. and GANNAM, A., 1999. Effect of partial and total replacement of fish meal on growth and body composition of sunshine bass Moronechrysops $\times$ M. saxatilis fed practical diets. Journal of the World Aquaculture Society, vol. 30, no. 4, pp. 443-453. http://dx.doi. org/10.1111/j.1749-7345.1999.tb00992.x.

WILSON, R.P., 1989. Protein and amino acid requirements of fishes. In: S.Y. SHIAU, ed. Progress in fish nutrition. Keelung: National Taiwan Ocean University. Marine Food Science Series, no. 9.

YAMAMOTO, T., SUGITA, T. and FURUITA, H., 2005. Essential amino acid supplementation to fish meal-based diets with low protein to energy ratios improves the protein utilization in juvenile rainbow trout Oncorhynchus mykiss. Aquaculture, vol. 246, no. 1-4, pp. 379-391. http://dx.doi.org/10.1016/j. aquaculture.2005.02.013.

ZUO, R., HOU, S., WU, F., SONG, J., ZHANG, W., ZHAO, C., CHANG, Y., 2017. Higher dietary protein increases growth performance, anti-oxidative enzymes activity and transcription of heat shock protein 70 in the juvenile sea urchin (Strongylocentrotus intermedius) under a heat stress[J]. Aquaculture and Fsheries, vol. 2 , no. 1, pp. 18-23. 